\title{
Interviu cu dll. dr. ing. Nicolae Doniță, membru al Academiei de Știīnțe Agricole și Silvice „Gheorghe Ionescu-Șișești”, Secția Silvicultură
}

\section{Laurențiu Giornei}

Profesorul Nicolae Doniţă s-a născut la Chişinău, la 20 noiembrie 1929, într-o familie de intelectuali (bunicul fiind preot la Hirişeni, apoi la Răciula, iar tatăl, Boris Doniţă, judecător şi apoi avocat la judecătoria Călăraşi). A urmat şcoala primară în oraşul natal, iar după 1940 România este obligată să cedeze părţi însemnate din teritoriul ei,

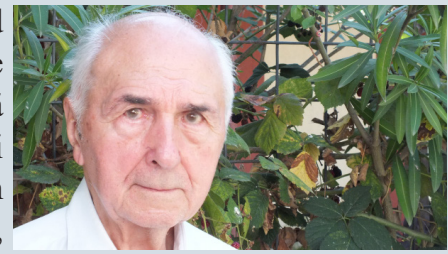
cu o popula-

ţie majoritar românească, părăsește Basarabia şi se refugiază împreună cu familia în teritoriul românesc nedezmembrat, unde îşi continuă studiile - liceul la Turda, iar între 1950 - 1955 cursurile Facultăţii de Silvicultură a Institutului Forestier din Braşov. Drama dezrădăcinării a fost amplificată de pericolul de a fi exmatriculat din cauza originii sale sociale, considerată „nesănătoasă” la acea vreme, și a fugii din calea comunismului, după ocupația sovietică a Basarabiei. A fost salvat de colegii de facultate care, cunoscându-1 şi apreciindu-1, au refuzat în unanimitate să voteze un act discriminatoriu, în şedinţa publică în care a fost pusă în discuţie exmatricularea.

La scurt timp după absolvire, după o stagiatură la OS Sebiș - județul Arad, în 1956, este angajat în cadrul Colectivului Forestier al Academiei, la recomandarea unuia dintre profesorii săi, cunoscut om de ştiinţă, academici- anul C.C. Georgescu. Aici îşi începe cariera de cercetător sub conducerea profesorului Sergiu Paşcovschi, reputat cercetător, cel care a descris tipurile de pădure din România.

Între timp, Colectivul Forestier este încadrat în Centrul de Cercetări Biologice, care, ulterior, devine Institutul de Biologie al Academiei. Colectivul Forestier este integrat în structura Laboratorului de Ecologie al Institutului. Lucrează alături de alţi specialişti recunoscuţi din domeniile ştiinţelor biologice şi silvice: I. Popescu-Zeletin, Al. Beldie, I. Vlad, C. Chiriţă, Gr. Eliescu, At. Haralamb, Alice Săvulescu, Ana Paucă, Ev. Soroceanu-Puşcariu etc.

În anul 1971, cercetătorii silvicultori din Institutul de Biologie al Academiei sunt transferaţi la Institutul de Cercetări şi Amenajări Silvice (ICAS), unde se constituie un laborator de Ecologie Forestieră. Va fi şeful acestui laborator începând cu anul 1975, până la pensionarea Domniei sale, în anul 1997. A continuat activitatea de cercetare şi după pensionare, colaborând la realizarea a numeroase proiecte de cercetare derulate în cadrul Laboratorului de Ecologie Forestieră din ICAS.

A obţinut titlul de doctor în Agronomie, specialitatea Silvicultură, la Facultatea de Silvicultură şi Exploatări Forestiere a Universităţii din Braşov, în anul 1970, cu teza „Cercetări geobotanice şi silviculturale asupra şleaurilor din Podişul Babadag".

A obţinut două burse de pregătire profesională în Germania: i) 1970-1971 bursier Ale- 
xander von Humboldt al Institutului de Sistematică şi Geobotanică al Universităţii din Göttingen; ii) 1985-1986 bursier Alexander von Humboldt al Institutului de Silvicultură al Landului Baden-Württemberg.

A publicat în calitate de autor unic, autor principal sau coautor peste 250 de lucrări ştiinţifice, din care 2 tratate (Ecologie forestieră, 1978; Silvicultura pe baze ecosistemice, 1997), 30 de cărţi sau capitole de cărţi, dintre care 12 au apărut la edituri din străinătate, 15 hărţi, dintre care 2 au apărut la edituri din străinătate, 8 manuale, ghiduri de bune practici, peste 200 de articole ştiinţifice, dintre care multe au fost publicate în reviste din străinătate.

În cele peste şase decenii de activitate ştiinţifică, domnul prof. dr. ing. Nicolae Doniţă s-a dezvoltat şi remarcat ca o personalitate proeminentă a ştiinţelor silvice, deschizător de drumuri, întemeietor de şcoală şi formator de specialişti, care a avut şi încă are contribuţii fundamentale la creşterea şi dezvoltarea silvologiei în ţara noastră, în domenii de mare importanţă, cum sunt: ecologia forestieră, fitocenologia şi tipologia pădurilor, cartografia forestieră, biodiversitatea pădurilor şi conservarea acesteia.

1. Din cei nouăzeci de ani pe care urmează să-i împliniți în 2019, 70 sunt legați de pădure, ceea ce poate părea mult chiar și din punctul de vedere al unei vieți obișnuite. Care sunt cele mai importante aspecte legate de viață în general, și de cea profesională în special, care se desprind dintr-o așa îndelungată experiență?

Mai exact sunt 69 de ani, din care 5 în facultate și 64 în profesie. Nu am avut la început o viață ușoară, sunt basarabean, de două ori refugiat, crescut în vremuri grele. Am beneficiat însă de o solidă pregătire în liceele și facultatea pe care le-am urmat. $\mathrm{Nu}$ știu ce aș fi făcut în profesie dacă profesorul meu de Botanică, din facultate, Constantin C. Georgescu, membru corespondent al Academiei, nu m-ar fi adus în cercetare, la Colectivul Forestier al Academiei, pe care îl conducea. Și dacă nu aș

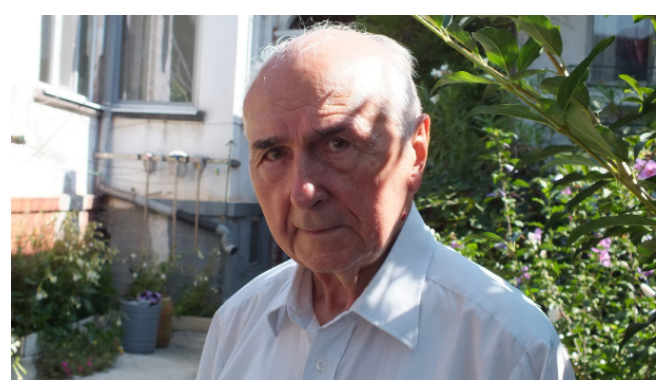

fi avut, ca prim-îndumător, pe inginerul Sergiu Paşcovschi, care de la început m-a antrenat în tematica de tipologie și în elaborarea hărții forestiere, domenii în care nu am încetat să lucrez. Ceea ce am învățat de la ei și din opera lor vastă, a fost baza de la care am pornit și m-am dezvoltat.

2. Începuturile carierei în silvicultură se leagă de cercetările desfășurate într-o zonă complexă din punct de vedere ecologic a țării, și anume Podișul Babadag din Dobrogea. Cum se văd acum primii pași în cercetare ai unui tânăr proaspăt venit de pe băncile facultății, care sunt amintirile legate de oamenii și de colectivul în care a activat și cum i-au influențat aceștia cariera viitoare?

Cercetarea ecologică complexă a pădurilor și pajiștilor din Podișul Babadag a fost determinată de desființarea Colectivului Forestier și crearea în Centrul de Cercetări Biologice, nou înființat, a unui laborator de ecologie, primul din țară, în care am fost încadrat, împreună cu profesorul Ion Popescu Zeletin, membru corespondent al Academiei, abia ieșit din închisoare, și colegii Constantin Bândiu și Vasile Mocanu. Ulterior au mai fost angajaţi doi biologi, Mihaela Paucă și Gheorghe Dihoru. Șefã de laborator a fost, la început, profesoara Ana Paucă, de la Universitatea București. Conducerea centrului, în special Alice Săvulescu, membră a Academiei, a insistat să conturăm o temă nouă, de amploare. Și, cunoscând literatura, am convenit să organizăm o cercetare ecologică complexă în ecosisteme cât mai naturale. Pentru că în cercetările pe care le întreprinsesem anterior, am cunoscut pădurile și stepele din Dobrogea, am 
propus și s-a hotărât să înființăm un staţionar la Babadag. Impreună cu colegii zoologi din alt laborator (condus de profesorul Grigore Eliescu, membru corespondent al Academiei), am cercetat timp de 7 ani, în cele mai reprezentative ecosisteme și rezultatele, primele de acest fel din țară, s-au publicat în două volume. Am avut un colectiv de entuziaști, care nu au pregetat să se consacre acestui nou tip de cercetare. Și am lucrat intensiv, fără neînțelegeri sau conflicte, până când, noi silvicultorii, a trebuit să trecem în alt institut de silvicultură, în 1970, când s-au făcut reforme în cercetare. Și în ICAS, în care s-a format un laborator de ecologie forestieră, am încercat să promovăm asemenea cercetări în ecosisteme din toate formaţiile forestiere, creând o rețea de staționare. Din diferite motive, nu s-a putut realiza continuarea acestei cercetări. Am revenit la ele abia în anii 1990-1992, când am studiat complex cultura de arbori și arbuști și care estecomportamentul ecologic al arborilor în climat și pe soluri de stepă.

3. Prin intermediul unei burse de cercetare a Fundaţiei Alexandru von Humboldt în Germania, ați avut șansa de a vă specializa în domeniul ecologiei la Institutul de Sistematică şi Geobotanică al Universităţii Göttingen, sub conducerea prof. dr. H. Ellenberg, iniţiatorul Programului Biologic Internaţional. Ulterior, ați colaborat la realizarea mai multor proiecte internaționale, de exemplu "Harta de vegetaţie a Europei", cercetarea populaţiilor de ierburi din pajiştile Munţilor Apenini şi din Alpii Italieni. Cum au contribuit aceste experiențe la formarea Dvs. profesională? Ați putea nominaliza principalele diferențe în ceea ce privește cercetarea științifică de la noi, comparativ cu țările având o cultură științifică mai îndelungată? În cadrul bursei Humboldt m-am ocupat, în continuare, sub conducerea profesorului Heinz Ellenberg, cunoscut ecolog, autorul unei clasificări ecologice a vegetației lumii, de aspecte metodologice de cercetare a biomasei și populațiilor pe care le-am aplicat apoi și în cercetările asupra pajiștilor, din Munții Apenini și Alpi, împreună cu profesorul Franco Pedrotti, de la Universitatea din Camerino, și soția mea, Doina Ivan. În timpul specializării din Germania $\mathrm{m}$-am putut documenta de problemele ecologiei noi, care începea să se dezvolte. Dar am putut cunoaşte și mulți dintre cei care se afirmaseră în studiul vegetației și al noii ecologii. În afară de conducătorul meu, am cunoscut și discutat cu Heinrich Walter, autorul marii monografii a vegetaţiei lumii, cu Reinhold Tüxen, fitosociolog și cartograf al vegetației din Germania, Pierre Duvignaud, autorul "Sintezei ecologice" din Belgia, Robert Whittaker, cunoscut ecolog din SUA, şi alții. Aceste contacte și documentări mi-au permis ca, la sugestia profesorului Grigore Eliescu, membru al Academiei, cu Ștefan Purceleanu, Igor Ceianu și Alexandru Beldie, să elaborăm și să publicăm, în 1977, Tratatul de Ecologie Forestieră, bazat pe teoria sistemelor. A fost un alt model de a prezenta structura pădurii, pe populații, biocenoze și mediu în conceptul de ecosistem și desfășurarea procesului ecosistemic de producere, consum şi descompunere a materiei organice. A fost arătat și rolul ecologiei în fundamentarea amenajamentului, a silvotehnicii, a protecției pădurii, a gospodăriei vânatului, cât și în protecția mediului. În formă de curs, 1-am introdus și în învățământul superior pentru a sublinia rolul hotărâtor al ecologiei în silvicultură. Dar cred că nu numai inginerii trebuie să fie bine orientați în ecologie ci și întreg personalul silvic, inclusiv muncitorii, care lucreză efectiv în pădure. Nu se pot face lucrări de calitate cu muncitori ai unor firme particulare, culeși de pe drumuri, ci numai cu echipe de oameni specializați, stabile în ocoalele silvice. Şi nu trebuie uitat că și proprietarii de pădure au nevoie de un mimin de cunoștințe despre caracterul ecologic pe care trebuie să le aibă intervențiile gospodărești.

4. Dintre programele și proiectele de cercetare la nivel național sau chiar internațional - unele foarte importante - pe care le-ați coordonat, vă rugăm să le nominalizați pe cele pe care le considerați drept cele mai relevante realizări, pentru științele silvice, pentru practica silvică. Dacă au existat, care ar fi nereușitele? În ipoteza că, în prezent, ați fi în plină activitate și ați coordona un colectiv de cercetare, care ar fi direcțiile sau temele de cercetare prioritare pe care ați dori să le abordați? 
Dintre proiectele de cercetare la care am lucrat cele mai relevante pentru științele şi practica silvică sunt hărțile pădurilor, în special ultima, pe unităţi ecosistemice, zonarea și regionarea pădurilor, tipologia pădurilor pe baze ecosistemice, contribuțiile la cunoașterea pădurilor virgine, tratatul de Ecologie Forestieră, evaluarea comportamentului ecologic al multor specii lemnoase în condiții de climă și sol de stepă.

Dintre nereușite a fost încercarea de a aplica cercetări ecologice complexe în toate formațiile forestiere. Este un proiect care trebuie reluat pentru o mai aprofundată cunoaștere ecologică a pădurilor noastre încă foarte puțin cunoscute din acest punct de vedere și pentru a evidenția specificul lor regional.

5. În decursul îndelungatei activități profesionale ați lucrat alături de reputați cercetători din țară și din străinătate. Cărora dintre ei le datorați cel mai mult, cum v-au influențat cariera? Dacă ar fi să nominalizați, care ar fi cel mai important nume?

Începând din 1960 am publicat mai multe hărți forestiere și de vegetație în ansamblu. Dar cea mai importantă contribuție cartografică a fost cea de la Harta de Vegetaţie a Europei, publicată în anul 2000, după 20 de ani de lucru. Am avut șansa de a cunoaște și de a lucra cu specialiști remarcabili, de la care am avut mult de învățat. Menționez în mod deosebit familia Neuhäusl din fosta Cehoslovacia, Udo Bohn din Germania, Ivan Bondev din Bulgaria, academicianul E. M. Lavrenco și colectivul său din Rusia, Franco Pedrotti din Italia, Atilla Borhidi din Ungaria, I. Matuszkiewicz din Polonia, H. Wagner din Austria și alții.

6. Poate fi menționată o contribuție notabilă a științei silvice românești la silvicultura europeană sau globală? Care sunt premisele de la care pornesc astfel de performanțe în știință și ce ar trebui făcut în prezent de către știința silvică românească pentru a tinde spre așa ceva?

O contribuție notabilă a științelor şi practicii românești la silvicultura europeană este, în primul rând, sistemul original de amenajare a pădurilor și zonarea funcțională a pădurilor, prin care s-a făcut amenajarea întregului fond 54 forestier, într-un timp în care puține țări din Europa aveau amenajate toate pădurile. Pentru conceperea metodei de amenajare, cât și pentru elaborarea tabelelor de producție, prof. Ion Popescu Zeletin a primit în anul 1970 prestigiosul premiu „W.L. Pfeil” al Fundaţiei F.V.S. din Hamburg, Germania. Au fost contribuțiile românești la viața științifică a IUFRO, când oameni de știință din România au condus diviziuni ale organizaţiei, a fost elaborarea dicționarului de amenajament pentru IUFRO (Filimon Carcea), a fost bibliografia mondială a lucrărilor de inventariere a pădurilor (A. Alexe), au fost investigațiile asupra pădurilor virgine (I. Popescu Zeletin, N. Rucăreanu, A. Rădulescu, J. Fröhlich), inventarierea resurselor genetice forestiere la speciile de foioase din sud-estul Europei (I. Blada, N. Doniță).

7. În decursul carierei ați condus și format colective de cercetare sau ați contribuit la formarea unor studenți și doctoranzi, pentru mulți dintre ei fiind modelul profesional și uman la care se raportează. Care ar trebui să fie principiile de la care trebuie pornit în relaționarea cu tinerii cercetători în formare și cât de mult contează exemplul personal în aceasta? Ce abilități trebuie să aibă un modelator de spirite "căutătoare", un creator de școală? Care ar fi rolul "școlilor de gândire" - mai direct, al colectivelor (de cercetare, din învățământ) - în această formare?

La multe proiecte am lucrat cu colective mari de cercetare, totdeauna le-am format numai cu acordul celor care au dorit să colaboreze şi am avut libertatea de a cerceta cum consideram necesar pentru a răspunde la ceea ce se cerea pentru proiect şi a lucra la timp datele necesare. Se evitau astfel nemulțumiri și conflicte.

8. Din aceeași perspectivă, sunteți unul dintre cei care au lăsat „,urmași”, în prezent specialiști recunoscuți și apreciați, ce activează în universități, institute de cercetare, muzee de științe naturale. Ce sfaturi leați da celor pe care i-ați îndrumat și ce așteptări ați avea de la ei?

Am contribuit, cât s-a putut, pentru a forma noi generații de ingineri și specialiști de înaltă calificare. Am predat cursuri de Dendrologie, Eco- 
logie Forestieră, Geografie Forestieră la mai multe facultăți și am condus lucrări de doctorat la 14 doctoranzi. Cel ce vrea să învețe pe alții poate să o facă numai dacă are solide cunoștințe în domeniu, din care să știe să selecteze esențialul, dacă a făcut cercetare în domeniu pentru a vorbi și din experiența proprie. Trebuie să aprecieze corect eforturile de pregătire la studenți, iar la doctoranzi, să-i sfătuiască permanent și să verifice veridicitatea datelor. Sunt bucuros și mândru că cei mai mulți doctori, pe care i-am format, s-au afirmat în cercetare și învăţământ și au devenit specialiști cunoscuți. Am certitudinea că toți nu vor abandona calea pe care am pornit și vor fi demni slujitori ai pădurii românești.

9. Silvicultura, care în esență este ecologie aplicată, are drept obiect de activitate cel mai complex ecosistem de pe glob. Cum poate contribui în continuare ecologia la dezvoltarea unor baze ecosistemice ale silviculturii? Considerați benefică orientarea acesteia în direcția apropierii de natură, spre o mai bună asimilare și aplicare a legităților ecologice în practica silvică?

Fără îndoială că din experiența noastră proprie, din tendințele clare ale silviculturii europene, exprimate și în normele de certificare a pădurilor, din experiența societății Pro Silva Europa, trebuie să promovăm silvicultura durabilă, apropiată de natură, bazată pe tehnologii fundamentate ecologic, protectoare de pădure.

10. Profesia de inginer silvic implică o temeinică pregătire multi- și transdisciplinară: biologică, ecologică, geografică, inginerească, economică, socială. Cum apreciați, din această perspectivă, formația ecologică prezentă a inginerului silvic, cel ce are în mâini soarta pădurilor noastre? Este aceasta adecvată cerințelor unei silviculturi pe baze ecosistemice? $\mathrm{Nu}$ numai inginerul silvic trebuie să capete solide cunoștințe de ecologie. Întregul personal de execuție, inclusiv muncitorii care lucrează direct în pădure, trebuie să aibă minim de cunoștințe ecologice pentru a înţelege de ce şi cum se fac lucrările.
11. În cei aproape 70 de ani de activitate științifică, de legătură directă cu sectorul forestier, pădurea și silvicultura românească au urmat un drum destul de sinuos, cu perioade mai mult sau mai puțin favorabile. Într-o retrospectivă istorică a acestui parcurs: de la perioada interbelică - în care s-a dezvoltat un cadru legislativ și institutional favorabil pădurii, la naționalizarea pădurilor - cu crearea unui cadru unitar de gestionare a acestora, trecând prin perioada comunistă - cu un prim deceniu de exploatare brutală a pădurilor de către Sovromlemn, urmat de alte trei decenii de gestionare rațională, până la perioada de după 1990 - de tranziție de la economia centralizată la economia de piață, care au fost - în opinia Dvs. - cele mai benefice și cele mai nocive trei aspecte pentru pădurea românească ce pot fi menționate?

Am ajuns să cunosc și cele bune și cele rele din gospodărirea pădurilor noastre în ultimul secol. Voi releva care mi s-au părut bune și care nocive. Benefice: (i) în perioada interbelică: crearea Casei Autonome a Pădurilor Statului și a Institului de Cercetări Experimentale Silvice; (ii) în perioada zisă socialistă: naționalizarea pădurilor, care a făcut posibilă amenajarea și zonarea integrală a fondului forestier şi organizarea unei gospodării a pădurilor bazată pe dezvoltarea puternică a cercetării și învățământului și introducerea în practică a rezultatelor, mai ales după 1975 până în 1995; (iii) în perioada trecerii spre capitalism: păstrarea fondului forestier de stat și înființarea Regiei Naționale a Pădurilor, care îl gospodărește cum se poate de bine; supraviețuirea cercetării silvice și transformarea ei în institut național. Nocive: (i) în perioada interbelică: pierderea a 1 milion de ha de pădure prin reforma agrară; (ii) în perioada zisă socialistă: exploatarea peste posibilitate a pădurilor accesibile pentru plata datoriilor de război și furnizarea de materie lemnoasă ieftină pentru industria prelucrătoare în dezvoltare; (iii) în perioada tranzitorie spre capitalism: modul cum au fost retrocedate pădurile din punct de vedere legal și real și lipsa unui control eficient al exploatărilor ilegale care au urmat și a modului cum s-au gospodărit sau mai bine zis nu s-au gospodărit acele păduri. 
12. Experiența de care am amintit mai sus - gândind la seria temporală a acumulărilor legate de pădure, perspectiva geografică - gândind la primele hărți ale pădurilor din România la care ați contribuit, împreună cu cea ecosistemică - gândind la cunoscuta tipologie a pădurilor pe baze ecosistemice, sunt argumente pentru o opinie personală (științifică, eventual la scări multiple) asupra pădurii și a silviculturii. Ce îi lipsește și ce ar trebui întreprins pentru a corecta anumite neajunsuri, unele poate justificate, ale silviculturii românești?

$\mathrm{Nu}$ există încă un control social organizat asupra a ceea ce se întâmplă cu pădurea și în silvicultură, nici în plan legislativ, nici în plan administrativ central, de aceea există și o criză a sectorului. Controlul s-ar putea efectua printr-un consiliu consultativ format din reprezentanţi ai proprietarilor şi a celor ce administrează direct pădurile, din învățământ, cercetare, ONG-uri active în domeniu. Acest consiliu ar trebui să analizeze legile şi măsurile propuse de organele centrale și să ia atitudine, pe orice cale, pentru a împiedica pe cele ce pot afecta pădurea sau silvicultura.

13. Pădurea, prin serviciile de mediu și sociale pe care le oferă societății, alături de bunurile economice pe care le aduce proprietarului, este un bun comun. Cu toate acestea, am putea spune că, în prezent, respectul față de acest bun comun este la un nivel scăzut. De ce credeți că s-a atrofiat grija românului față de pădure și ce ar trebui întreprins pentru o mai bună conștientizare publică a acesteia?

Marin Drăcea a sesizat că românul nu are conștiință forestieră și a încercat să o creeze, dar nu a avut urmași. Acest lucru se poate face prin ceea ce a propus: introducerea în învățământul de toate generațiile, de lecţii asupra pădurii şi silviculturii. A arătat prin ceea ce a făcut, că este necesară și o propagandă susținută oral sau prin mass-media.

14. În România există 415.000 de mici proprietari de pădure, iar suprafețele pe care le dețin sunt, în general, de sub 100 hectare; cei mai mulți au moștenit aceste păduri și foarte puțini dintre ei își permit să le administreze corespunzător. Considerați că ar fi oportun ca statul, prin Romsilva, să cumpere acele suprafețe?
În mica proprietate a majorităţii acestor proprietari nu se poate face silvicultură normală. S-au făcut asocieri și trebuie stimulate în continuare. Dar statul ar trebui să intensifice și să permanentizeze achiziţionarea micilor proprietăți.

15. În ultimul număr al revistei ați publicat un articol din care am reținut că "silvicultorii basarabeni și-au făcut datoria" ... A existat vreun moment în care și-a pus cineva problema loialității silvicultorilor basarabeni în susținerea silviculturii din România? În legătură cu aceasta, cunoscând implicarea Dvs. în problematica pădurilor de pe cealaltă parte a Prutului, cum credeți că ar putea contribui în prezent silvicultura românească - inclusiv într-un context simbolic - la o "restituire" a contribuțiilor silvicultorilor basarabeni primite în trecut către spațiul de baștină?

Silvicultorii basarabeni au contribuit într-adevăr la programul științelor silvice în România și nimeni nu a pus la îndoială loialitatea lor.

S-au implicat după 1990 şi în sprijinirea confraţilor lor din Republica Moldova. Prin stăruința doctorului Filimon Carcea s-a organizat amenajarea pădurilor lor prin metoda românească și s-au pregătit cadre pentru a continua în același fel.

Alţi colegi au participat la această amenajare și s-au îngrijit de procurarea literaturii silvice românești pentru a-i sprijini și au participat la rezolvarea altor probleme, la cercetări în comun și la pregătirea de cadre superioare.

În învăţământul nostru silvic au fost pregătiti mulți silvicultori din R. Moldova și chiar în cercetarea noastră activează unii dintre ei.

16. În același număr al revistei am avut privilegiul de a-I intervieva pe președintele Academiei Române, reputatul istoric loan-Aurel Pop. Meritele Dvs. profesionale v-ar fi calificat pentru accederea în acest for al culturii și științei românești, însă acest lucru nu s-a concretizat până în prezent. Cum se vede dintr-o perspectivă pur umană această nerealizare și cum se leagă aceasta cu experiența îndelungată de viață de care am amintit la începutul interviului?

Alegerea mea, direct ca membru titular, în Academia de Științe Agricole și Silvice, în anul 1991, a fost desigur o recunoaștere a ceea ce am făcut până atunci. Am primit și alte onoruri: 
Medalia Meritul Ştiinţific, Medalia Dimitrie Cantemir a Academiei de Științe a Republicii Moldova, două titluri de doctor honoris causa, diverse diplome. Aportul meu în știință nu a rămas neobservat.

17. La finalul dialogului nostru, am dori să transmiteți cititorilor revistei câteva gânduri despre cercetarea forestieră românească, pe care ați slujit-o peste 60 de ani.

Cercetarea a supraviețuit prin efortul deosebit al cercetătorilor și se desfășoară și astăzi într-un institut național, precum și în învățământ.

Sistemul de până acum al formării tematicii de cercetare nu a permis însă o dezvoltare unitară a cercetării în toate domeniile silviculturii, unele chiar dispărute, și axată pe o problematică complexă, corectă și gândită și în perspectivă. Este nevoie de un program echilibrat, comun pentru cercetare-învățământ, pentru a dezvolta toate științele silvice și aplicaţiile lor practice, atât pe probleme curente de rezolvat urgent pentru silvicultura de stat și cea privată, dar având în vedere, în perspectivă și dezvoltarea silviculturii regionale ținând seama de schimbările climatice. Dar pentru aceasta este necesară o atentă analiză a ceea ce s-a făcut în ultimii 30 de ani și să fie elaborat un program realist pentru viitor. Printr-un asemenea program s-ar stimula și dezvoltarea cercetărilor în toate specialităţile necesare silviculturii regionale. 